\title{
Estimation of Boron Contamination Sources of Groundwater in the Central Boso Peninsula, Chiba Prefecture, Japan.
}

\author{
Kentaro TAKAI* and Norio TASE**
}

\begin{abstract}
The purposes of this study are (1) to describe the extent of boron contamination of groundwater in the Central Boso Peninsula and (2) to identify possible sources of the contamination. Out of 147 samples, boron concentrations of 21 samples exceeded the former guideline value of $0.2 \mathrm{mg} / \mathrm{L}$. The contaminated wells are distributed locally. The groundwater with high boron concentrations has characteristics of higher values of $\mathrm{Na}, \mathrm{K}$, and $\mathrm{HCO}_{3}$ concentrations, $\mathrm{pH}$ and $\mathrm{EC}$, extremely lower value of $\mathrm{Ca}$ concentration and brownish colored water. The contaminated water is classified into two types of water, noncarbonate alkali and carbonate alkali types, whose contaminant sources are estimated as fossil water and marine sediments of deep layers, respectively.
\end{abstract}

Key Words: boron, groundwater, Boso Peninsula, contaminant source, fossil water

\section{要旨}

本研究では、環境庁による調査でホウ素による污染が確認されている、千葉県睦沢町の 瑞沢川流域と、市原市から大多喜町にかけての養老川流域を研究対象地域とし147本の地 下水サンプルを採取した。そして対象地域佃近の地下水中のホウ素濃度とホウ素含有地下

* 筑波大学環境科学研究科 (現 浜松市役所企画課)

Mater's Program in Environmental Sciences, University of Tsukuba (Now at Hamamatsu City Office)

** 筑波大学地球科学系

Institute of Geoscinece, University of Tsukuba, Tsukuba, Ibaraki 305-8571, Japan 
水の水質の特徴を明らかにし、ホウ素の起源を推定した。分析の結果、147サンプル中21 サンプルから旧指針值の $0.2 \mathrm{mg} / \mathrm{L}$ を超過するホウ素が検出された。ホウ素濃度が旧指針値 を超過していた井戸は比較的集中していることが多かった。ホウ素を比較的高濃度に含む 地下水では、 $\mathrm{Na}^{+} 、 \mathrm{HCO}_{3}^{-}$濃度、 $\mathrm{pH}$ や $\mathrm{EC}$ などの值が高く、弱アルカリ性を示し、 $\mathrm{Ca}^{2+}$ の 值は極端に低く、茶褐色に着色していることが多いなどの特徵があったが、水質データの クラスター分析によってアルカリ非炭酸塩型とアルカリ重炭酸塩型の 2 種類に分類され た。アルカリ非炭酸塩型の污染地下水についてはホウ素の主な供給源は化石水であること、 またアルカリ重炭酸塩型の地下水に関しては地質起源と推定された。

キーワード：ホウ素、地下水、房総半島、污染源、化石水

\section{1. はじめに}

ホウ素は、平成 5 年 3 月に水質污濁防止法の要 監視項目として0.2mg/L という指針值が設定され た物質である。急性毒性としては悪心、嘔吐、下 痢、腹痛などがあり、ホウ酸の中毒量は成人で $1 \sim 3 \mathrm{~g}$ といわれている(日本環境管理学会、 1994）。平成 8 年度の環境庁の「水質污濁に係る 要監視項目の調査結果について」では、ホウ素に ついて、全国で192本の井戸の調査結果がまとめ られて抢り、そのうち $5.2 \% に あ た る 10$ 本の井戸 で指針值を超過していた。近年問題となっている トリクロロエチレンをはじめとする揮発性有機塩 素化合物や、肥料起源の污染が深刻な硝酸性窒素 などと比べると顕著な污染はみつかっていない が、ホウ素による地下水污染も今後顕在化してく る可能性がある。実際、ホウ素の $5.2 \%$ という超 過率は、污染の顕在化が進み対応が急がれている 硝酸性窒素の超過率5.4\%に次いで高いものであ る。平成11年 2 月 2 日の中央環境審議会水質部会 の答申では、ホウ素を環境基準とすることが適切 であるとの提言がなされ、2 月22日付環境庁告示 により要監視項目から環境基準健康項目へ移行す

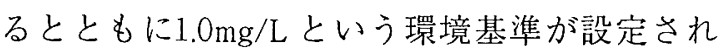
た。

現在ホウ素による地下水污染源について、自然 起源のものとして火山地帯の地下水、温泉排水、 地下水への海水の侵入などが、人為起源としては 金属表面の処理工場・ガラス工場・エナメル工場 などからの排水、石炭焼却灰の処分施設、半導体 などを生産する工場などが考えられている(建設
省、1997；眞柄ほか、1993）。しかし、従来の地 下水中のホウ素に関する研究は、後述するように 飛灰から溶出したホウ素の土壤中の移行に関する 電力中央研究所による一連の研究や、温泉水中の ホウ素濃度に関する研究などがあるものの、国内 における地下水中のホウ素に関して、污染の広が りや污染源なども含めた実際的な研究は十分に進 展しているとはいいがたく総合的な知見の集積が 必要と考えられる。

以上のような現状を踏まえ本研究では、過去の 環境庁による調査で高濃度のホウ素が検出されて いる地域において地下水中のホウ素濃度の分布状 況やホウ素含有地下水の水質特性を把握し、地下 水中のホウ素に関する基礎的なデー夕を得ること によって、ホウ素の起源の推定を行うことを目的 とした。研究対象地域には、平成 8 年度の地下水 要監視項目実態調査で $0.35 \mathrm{mg} / \mathrm{L}$ のホウ素が検出 された千葉県睦沢町の瑞沢川流域を選び、また比 較対照地域として養老川流域についても取り上げ た。

\section{2. ホウ素に関する従来の研究}

\section{1 自然界におけるホウ素の存在量}

ホウ素は、ホウ素鉱床にホウ砂やカーン石など として大量に含まれているほか、地球のほとんど の岩石、天然水中に微量ながら含まれている。地 球上のホウ素の存在量は、地殼平均で $10 \mathrm{ppm}$ (37 番目)、海水中に約 $4.5 \mathrm{ppm}$ ( 9 番目)である(桜井 · 田中、1993)。内海・磯崎 (1967)によると雨中、 雪中のホウ素は、それぞれ0.009ppm、0.005ppm 
できわめて微量しか存在していない。また、河川 水、湖沼水、地下水では通常0.01 0.1ppm ぐらい の範囲で含まれているといわれている。渡良瀬川 の平均值で $0.124 \mathrm{mg} / \mathrm{L}$ 、桐生川の平均值で $0.094 \mathrm{mg} / \mathrm{L}$ （日本化学会、1992）、多摩川で0.086mg/L (磯崎、 1975）という值が報告されている。水中でのホウ 素は、オルトホウ酸 $\left(\mathrm{H}_{3} \mathrm{BO}_{3}\right)$ として存在する。 $\mathrm{pH} 9.2$ 以下では三角形の配位構造である $\mathrm{B}(\mathrm{OH})_{3}$ と して存在するが、pH9.2以上では四面体配位構造 の $\mathrm{B}(\mathrm{OH})_{4}^{-}$として陰イオンで存在する。火山性の 酸性泉、あるいは酸性の火山性ガス濃縮水中では、 テトラフルオロホウ酸イオン $\mathrm{BF}_{4}^{-}$の形でも存在 している。また、ホウ素は植物にとって必須な元 素であり、特に高等植物では細胞の成熟と分化の 過程に重要な役割があることが知られている(桜 井・田中、1993)。

\section{2 地下水中のホウ素に関する従来の研究}

国内における地下水中のホウ素濃度に関する研 究は、温泉水や鉱泉水に関して行われたものが大 半である。武藤(1954) はホウ素を多く含む鉱泉水 について研究を進め、国内のホウ素を多く含む鉱 泉は、北海道の天塩地方と半島地方、岩手県の七 時雨山地方、山形県の蔵王周辺、群馬・長野両県 に密集していること、そして大部分の鉱泉の泉質 は、弱アルカリ性の冷泉で、ナトリウム、塩素、 重炭酸および遊離炭酸を大量に含有していること を指摘した。西村(1993) は、温泉中のホウ素含有 量を明らかにするとともに、他成分との関連等、 どのような温泉にホウ素含有量が大きいのか考察 し、ホウ素含有量の多い温泉水を、「化石水」型 のものと「火山発散物」型のものに分類した。そ して、「化石水型」は蒸発残査が大で、食塩が主 成分であり、海水に比べ硫酸イオンに乏しく、ヨ ウ素、臭素を多く含有するものとし、ホウ素の起 源については海性起源を示唆している。一方で火 山性酸性温泉群にもホウ素含有が多いことを指摘

し「火山発散物型」と定義している。

ホウ素の地中移行に関しては、電力中央研究所 による一連の研究がある。佐藤・坂田(1988)は、 石炭灰からの溶出元素の土壌中輸送モデルを開発 するための第 1 段階として、中性条件下で土壤力 ラム実験を行ない、ホウ素が易動性の元素である
ことを明らかとした。五十嵐・下垣 (1998)は、ホ ウ素の土壤・地下水系での移行挙動を評価するこ とは、石炭焼却灰に含まれる他の微量元素の移行 挙動を予測する上でも重要であるとして、ミニカ ラム試験やライシメータ試験を行い、 $10 \mathrm{mg} / \mathrm{L}$ 以 下の範囲では、ホウ素の吸着がヘンリー式で評価 できること、共存イオンの影響をほとんど受けな いことなどを明らかにした。

ホウ素の同位体に関する研究は、Davldson \& Basset(1993)によるものなどがある。Davldson \& Basset(1993) は、飛灰から地下水中への污染物質 の侵入をホウ素同位体を用いて確認する方法を検 討した。日本に抢けるホウ素同位体研究は石川・ 中村 (1989)によりレビューされている。国内にお けるホウ素同位体の研究は、日本列島の島弧火山 活動に関係する火山ガス凝縮水および温泉水につ いての $\delta{ }^{11} \mathrm{~B}$ に関する研究があるものの、情報が まだ不足しており、広範囲にわたる基礎的なデー 夕の蓄積および分析技術の改善が望まれている。

金子(1995)は、千葉県における161地点の地下 水を対象として、地下水の水質および貯留の特性 を明らかにした。そのなかで、千葉県において地 下水は水質加火山灰土地域、河成壤質土地域、 第三系粘質土地域、谷津田地域、海成砂質土地域 の 5 つのタイプに区分することが妥当であるとし た。そして、海成砂質土地域ではカルシウム、ナ トリウム、鉄、塩素、硫酸態硫黄、 $\mathrm{pH} 4.8$ アルカ リ度などとともにホウ素の濃度も高くなる傾向を 示すことを指摘している。

従来の研究をレビューしてみると、国内におけ るホウ素の研究は、污染という観点から研究され たものが皆無に等しいといえる。なお海外では、 前述したDavldson \& Basset(1993)や Leenhhouts et al. (1998)など污染の有無や污染源を特定する 手段として、ホウ素同位体を用いる研究が進めら れている。

\section{3. 研究の方法}

\section{1 研究対象地域の概略}

本研究の対象地域は、図 1 に示した千葉県睦沢 町の瑞沢川流域と大多喜町と市原市にまたがる養 老川流域である。瑞沢川流域を研究対象地域とし 

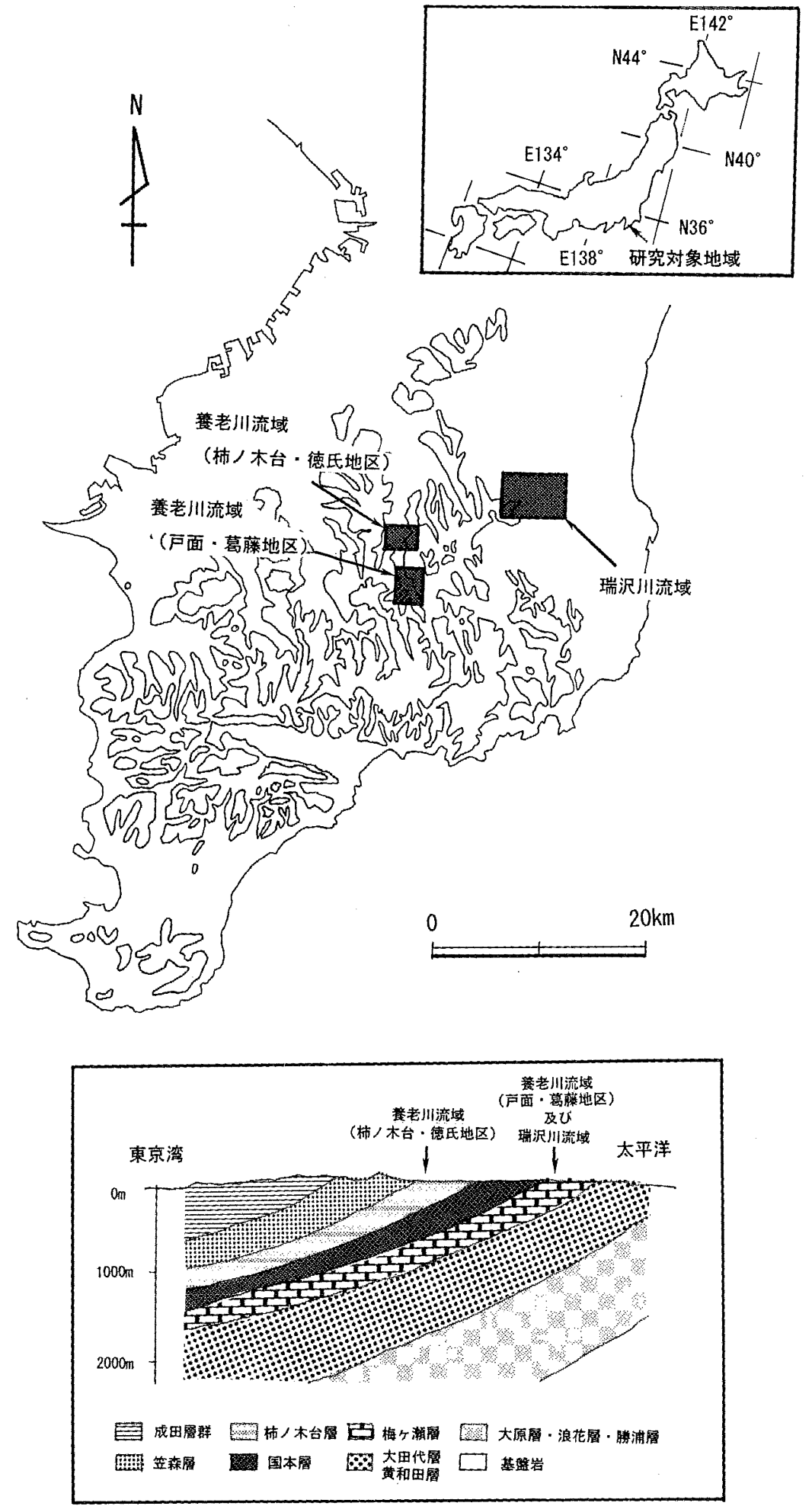

図 1 研究対象地域と地質 (北西から南東方向の断面)

Fig. 1 Study areas and geologic section 
た理由は、1)過去の調査で高濃度のホウ素が検 出されていること、2)地元自治体の協力が得ら れたこと、などである。養老川流域を研究対象地 域としたのは、瑞沢川付近と同一の地質であり比 較検討に適していたためである。

研究対象地域の瑞沢川流域は房総半島の中央部 よりわずかに南東よりにある。地形的には大多喜 町と接する南西側で標高が高く、東側で平坦地と なっており、標高は10～170m 程度である。地質 は第三紀層の砂岩と泥岩の互層からなり、豊富な 天然ガスを産出することで知られている。流域の 一部では、天然ガスが自噴しており、作物が枯れ るなどの被害がみられ、一部の地区ではガス拔き 等の対策がなされている。町から北北西に7.5km 離れた茂原市の気温と降水量の平年值はそれぞれ $14.8^{\circ} \mathrm{C} 、 1,675 \mathrm{~mm}$ である。流域のほぼ央に一宮 川の支流である瑞沢川が流れ、肥沃な沖積平野を 形成しており、中心産業のひとつである稲作を支 える源となっている。瑞沢川流域では、河川沿い の沖積地はほとんど水田として利用されている。

また、比較対照地域の養老川流域とは、大多喜 町葛藤地区と市原市戸面地区との境界にある温泉 街から下流の柿木台地区にかけての地域である。 養老渓谷温泉郷の泉質は、弱アルカリ性で、温泉 水は淡黄一黄褐色を呈し、薄い塩味を有すること が多く、天然ガスを伴うこともある。しかし、水 温は低く加熱利用されている。

\section{2 試料採取地点}

瑞沢川流域におけるサンプリングは1998年 8 月 19２2日にかけて大上地区を中心に上之郷、妙楽 寺地区で行った(図 2)。一般家庭で、杂倠用や飲料 水として使われている地下水を109サンプル(大上 73本、上之郷13本、妙楽寺23本) 採水した。この うち14サンプルは、井戸深が不明であり、18サン プルは10m 以深の井戸から採取したものである。 大上地区では過去の調査で比較的高い濃度のホウ 素が検出されており、できる限り多くの井戸から サンプルを採取した。また、大上地区と妙楽寺地 区では、合同資源産業株式会社のプラントから、 ヨード生産用に揚水されている化石水と考えられ る地下水を採取した。本研究でいう「化石水」と は、海水が地層堆積時に地層中につつみこまれ、
そのまま閉じこめられたと考えられる地下水のこ とで、その水質が、その後の続成作用を受けて、 海水に比べ $\mathrm{HCO}_{3}^{-} 、 \mathrm{I}^{-} 、 \mathrm{Br}^{-} 、 \mathrm{NH}_{4}^{+}$などが増加し、 $\mathrm{SO}_{4}^{2-} 、 \mathrm{Ca}^{2+} 、 \mathrm{Mg}^{2+}$ などが減少した地下水のこと である。

養老川流域におけるサンプリングは1998年11月 13、20日に行った。一般家庭や温泉街で使われて いる井戸から大多喜町葛藤地区で 8 本、市原市戸 面地区で 8 本、折津地区で 1 本、朝生原地区で 12 本、石神地区で 2 本、徳氏地区で 2 本、柿木台地 区で 5 本、合計で38サンプルを採取した。このう ち戸面地区の 2 本、葛藤地区の 4 本の井戸は、温 泉や私設のガス採取井戸として利用されているも のである。38の井戸のうち 7 サンプルは $10 \mathrm{~m}$ 以浅 の井戸から採取されたものであり、6サンプルは 井戸深が不明であった。

\section{3 対象地域付近の地質について}

大森ほか(1986)によると瑞沢川流域の主な地層 は、第三紀終わり頃から第四紀はじめ頃にかけて 大陸斜面の上一中部で堆積した砂がちの砂岩・ 泥岩互層の梅ヶ瀬層で層厚は約 $310 ４ 50 \mathrm{~m}$ である (図 1)。数 $\mathrm{m}$ の細〜中粒砂岩層に数一数十 $\mathrm{m} の$ 泥岩層をはさんだ状態が普通である。養老川流域 (戸面・葛藤地区) 付近の主な地質も梅ヶ瀬層であ る。この梅ヶ瀬層をはじめその下方にある大田代 層、黄和田層などは天然ガスを産出することで知 られている。黄和田層は、泥岩を主とし、薄い砂 岩をはさむ。大田代層は、泥岩と砂岩の互層から なる。梅ヶ瀬層の上位に当たるのが、国本層、柿 ノ木台層などである。国本層は、砂がちの砂岩と 泥岩の互層と塊状の砂質泥岩とからなる。柿ノ木 台層は、拈もに塊状の砂質泥岩からなる。本研究 の対象地域のひとつである養老川流域の柿ノ木台 地区は柿ノ木台層にあたる。

また、茂原市から市原市、江東区にかけての地 域は南関東ガス田と呼ばれ、水溶性天然ガスの生 産が盛んに行われている。この地域の天然ガスか ん水鉱床の成因については、半深海に堆積した有 機物が還元的な堆積環境のもとで分解してメタン となり、高圧のもとで化石水にとけてできたもの と考えられている(大森ほか, 1986)。瑞沢川流域 では、関東天然ガス開発と合同資源産業の 2 社が 

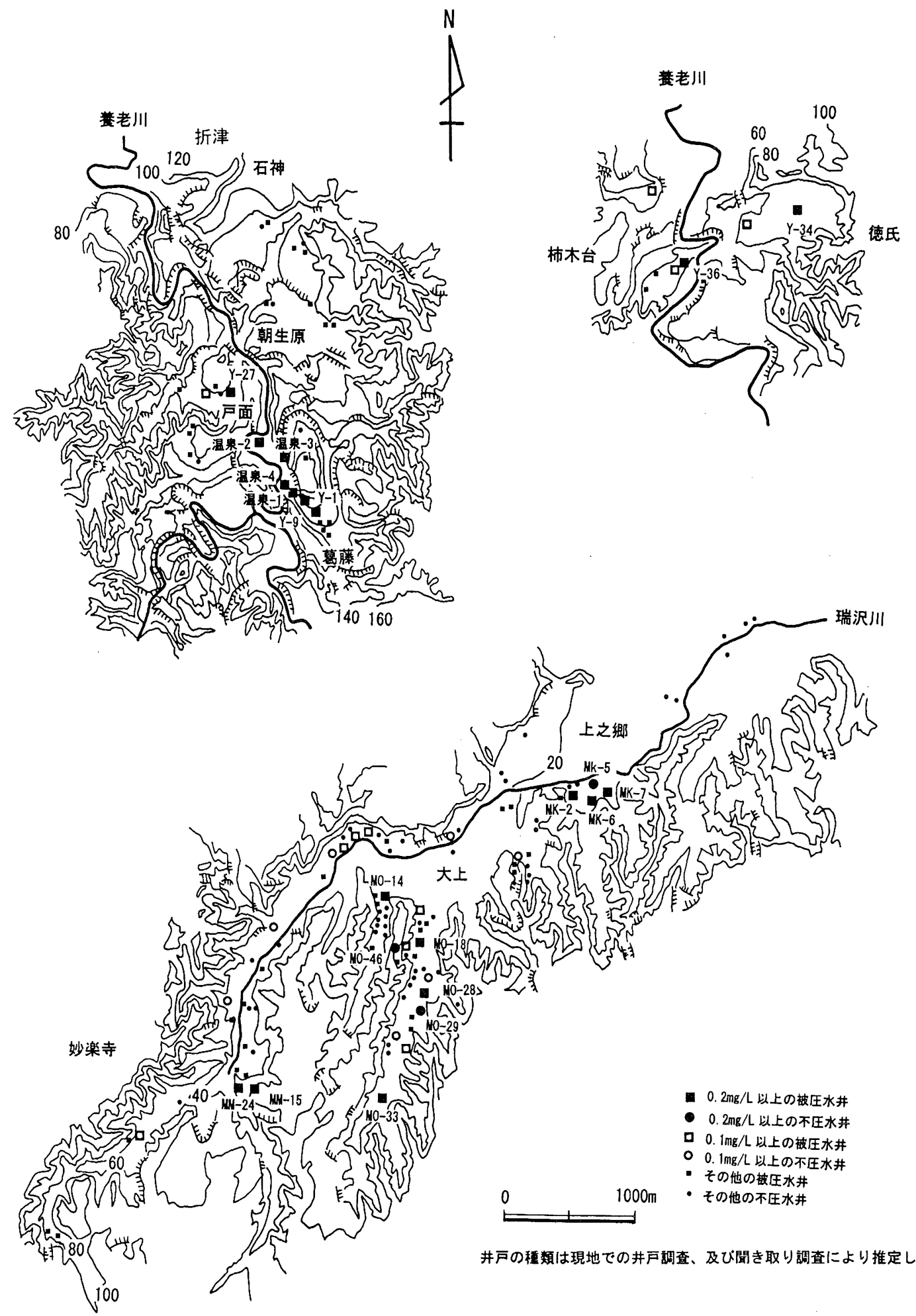

図 2 各流域におけるホウ素濃度の分布

Fig. 2 Areal distribution of boron conentration. 
鉱業権をもっており、深さ $1,200 \mathrm{~m}$ 程度の約 100 本 の井戸で生産を続けている。

ホウ素は粘土鉱物の $\alpha-\mathrm{Al}_{2} \mathrm{O}_{3}$ の表面のサイトに 吸着されるため、粘土鉱物に吸着されやすいこと で知られている(石川・中村、1989)。そのため、 粘土鉱物を主成分とする海成堆積岩は、一般に火 成岩に比べて多量のホウ素を含んでおり、泥岩や 頁岩のように粘土鉱物の多い岩石では、ホウ素含 有量が100ppm を越えることも珍しくないといわ れている。海成の砂岩・泥岩の互層である本研対 象地域の地質中には、ホウ素が高濃度で含有して いる可能性がある。

\section{4. ホウ素を高濃度に含む地下水の特徴}

\section{1 水質の分析方法}

ホウ素の試験方法として、JIS K 0102(工場排 水試験方法)では、メチレンブルー吸光光度法、 アゾメチン H 吸光光度法及び ICP 発光分析法が ある。また、上水試験法としては ICP 発光分析法 及びクルクミン吸光光度法が採用されている。本 研究では、指針值に対して十分な感度を持ち、か つ操作が簡便な ICP 発光分析法(ジャーレルアッ シュICAP-575)を用いてシーケンシャルでホウ素

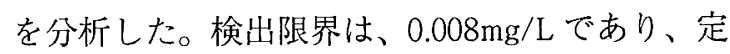

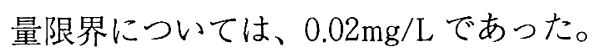

陽イオンなど $\left(\mathrm{Na}^{+} 、 \mathrm{~K}^{+} 、 \mathrm{Ca}^{2+} 、 \mathrm{Mg}^{2+} 、 \mathrm{Si} 、 \mathrm{Fe}^{3+} 、\right.$ $\left.\mathrm{Al}^{3+}\right)$ については、ジャーレルアッシュ社製 ICAP-757を用いてマルチシーケンシャルで行っ

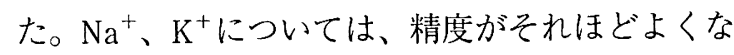
いため、高濃度のものについてはシーケンシャル で測定し直した。

陰イオン $\left(\mathrm{Cl}^{-} 、 \mathrm{NO}_{3}^{-} 、 \mathrm{SO}_{4}^{2-} 、 \mathrm{Br}^{-} 、 \mathrm{~F}^{-} 、 \mathrm{NO}_{2}^{-}\right.$、 $\left.\mathrm{PO}_{4}^{3-}\right)$ についてはイオンクロマトアナライザー (横河 IC7000) を使用した。重炭酸イオン $\left(\mathrm{HCO}_{3}^{-}\right)$ については、MR-BCG 混合指示薬を用いて $\mathrm{pH} 4.8$ アルカリ度として分析した。 $\mathrm{pH}$ 、水温、電気伝

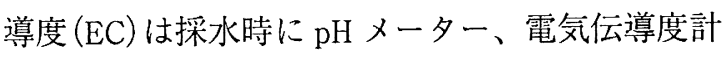
を用いて測定した。また、すべてのサンプルは、 電気伝導度が $400 \mu \mathrm{S} / \mathrm{cm}$ 以下になるように希釈 し、 $0.2 \mu \mathrm{m}$ のメンブランフィルターで濾過後、 分析に供した。

\section{2 污染地下水の水質の特徵}

ホウ素濃度の分布を図 2 に示した。またホウ素 濃度と $\mathrm{EC}$ や $\mathrm{HCO}_{3}^{-} 、 \mathrm{Na}^{+} 、 \mathrm{Ca}^{2+}$ 濃度との関係 を図 3 に示した。ホウ素は、主に被圧水井で検出 された。瑞沢川流域においてホウ素濃度が、旧指 針值の $0.2 \mathrm{mg} / \mathrm{L}$ を越えた井戸は、大上地区で 6 本、 妙楽寺地区で 2 本、上之郷地区で 4 本であった。 ホウ素濃度が高い井戸は比較的集中して存在する ことが多い。大上地区の碇谷、妙楽寺地区の荒川、 上之郷地区の山田谷付近に集中している。上之郷 地区では $0.55 、 0.64 、 0.77 \mathrm{mg} / \mathrm{L}$ という旧指針值の 2 倍以上の高い值のホウ素が検出された。

ホウ素が旧指針值を越えて検出されたサンプル では $\mathrm{Na}^{+} 、 \mathrm{HCO}_{3}^{-} や \mathrm{EC}$ な゙が高くなる傾向が あった(図 3 )。特に、 $\mathrm{Na}^{+}$は最高值で $434 \mathrm{mg} / \mathrm{L} 、$ 平均 $162 \mathrm{mg} / \mathrm{L}$ という高濃度で検出された。また $\mathrm{EC}$ が平均で $666 \mu \mathrm{S} / \mathrm{cm}$ という值になった。これ は、ホウ素濃度が定量限界值以下であったサンプ ルの平均 $\mathrm{EC}$ である $348 \mu \mathrm{S} / \mathrm{cm}$ と比べてかなり高 い值である。逆に $\mathrm{Ca}^{2+}$ の值は、ホウ素濃度が高 いサンプルでは小さくなる傾向があった。 $\mathrm{Cl}^{-}$の 濃度は他のサンプルと比較して大差がなかった。 また、 $\mathrm{pH}$ は7.6 9.0であり、弱アルカリ性を示し ていた。上之郷地区の指針值を超過している 1 サ ンプルについては、 $\mathrm{Na}^{+} 、 \mathrm{HCO}_{3}^{-} 、 \mathrm{EC}$ など以外に も $\mathrm{Cl}^{-} 、 \mathrm{NO}_{3}^{-} 、 \mathrm{Ca}^{2+}$ などが高い值を示している。 このサンプルを採取した井戸付近には畜舎があ り、牛を数頭飼育している。150mg/L という $\mathrm{NO}_{3}^{-}$ 濃度から考えると、この井戸の水質に限っては、 畜舎排水の影響を強く受けている可能性がある。

養老川流域において旧指針值を越えるホウ素が 検出された井戸は、38本中 9 本であった。そのう ち 6 本は養老渓谷温泉郷で温泉用、私設のガス採 取用として掘り出されているものであった。これ らの井戸のホウ素の濃度は、 $0.21 \sim 0.92 \mathrm{mg} / \mathrm{L}$ の間 であった。温泉用、ガス採取用として用いられてい る地下水は次のような共通した特徴を持つ。すなわ ち $\mathrm{pH}$ は弱アルカリ性（7.1８.9）を示し、主要な溶存 イオンは $\mathrm{Cl}^{-} 、 \mathrm{HCO}_{3}^{-} 、 \mathrm{Na}^{+}$などで、 $\mathrm{EC}$ は他の地 下水に比べ明らかに高い $(701 \sim 5,940 \mu \mathrm{S} / \mathrm{cm})$ など の特徵である。 $\mathrm{Na}^{+}$は平均で $888 \mathrm{mg} / \mathrm{L} 、 \mathrm{Cl}^{-}$は平

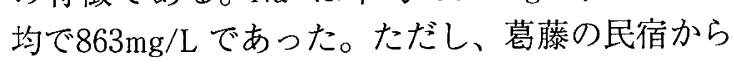
採取した EC が701 $\mu \mathrm{S} / \mathrm{cm}$ のサンプルからは $\mathrm{Cl}^{-}$ 

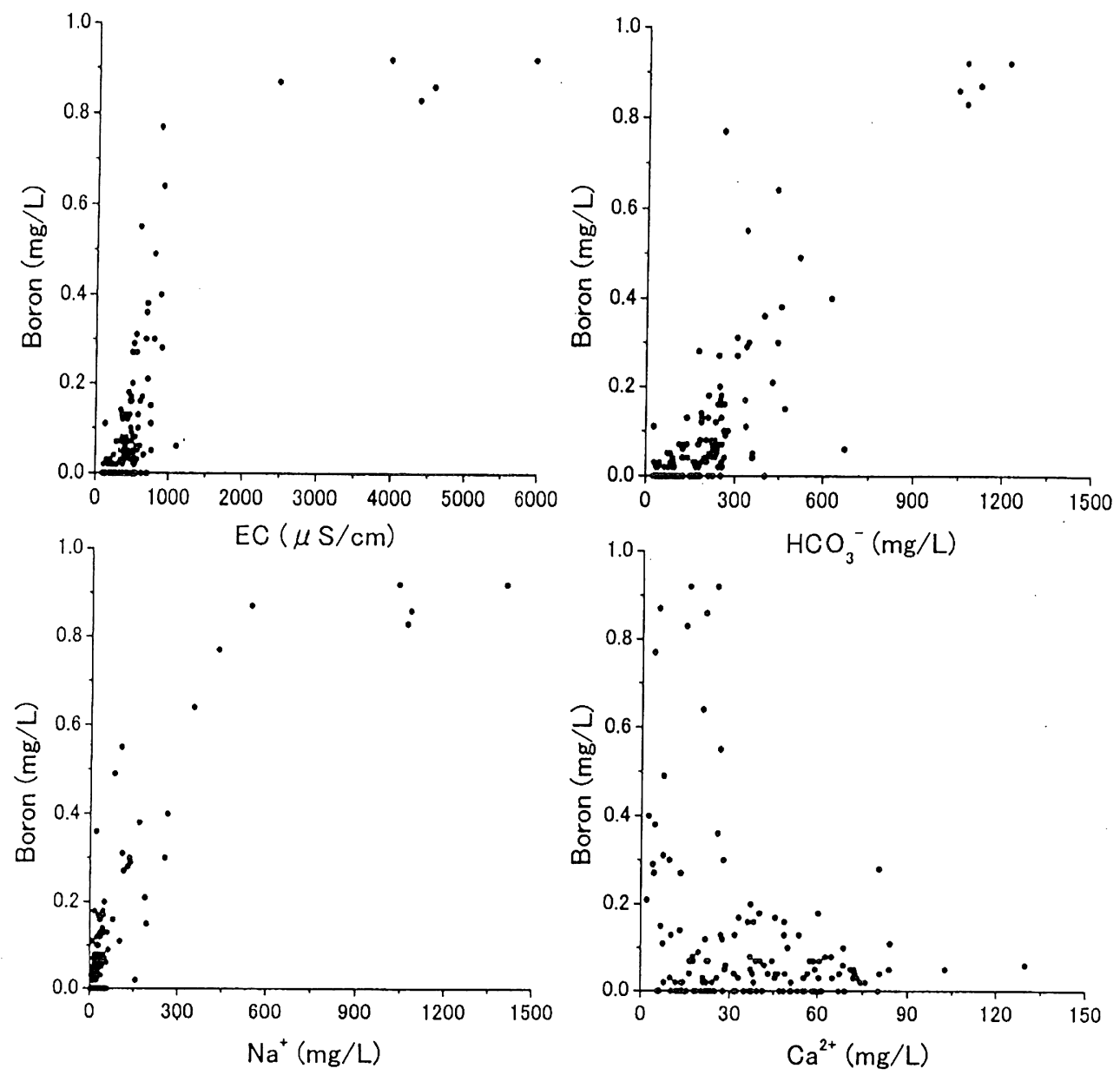

図 3 ホウ素と電気伝道度 (EC), 重炭酸イオン, ナトリウムイオン, およびカルシウムイオンとの関係

Fig. 3 Relationships between boron and electric conductivity, bicarbonate, sodium, and calcium.

が低濃度 $(7.5 \mathrm{mg} / \mathrm{L})$ で検出された。この井戸のホ ウ素濃度は $0.21 \mathrm{mg} / \mathrm{L} て ゙$ 他の温泉水に比べホウ素 濃度は特に低い值を示した。温泉水、ガス採取用 水はすべて黄色みがかった茶色を示していた。

残りの 3 本の井戸は、一般家庭で利用されてい る井戸であった。1本は風呂用として使われてい る井戸であり、 $0.40 \mathrm{mg} / \mathrm{L}$ という濃度のホウ素が 検出された。この井戸水を採取したのは、温泉郷 の戸面地区に隣接した市原市の朝生原地区であ る。この井戸の水質の特徵は、 $\mathrm{Na}^{+} 、 \mathrm{HCO}_{3}^{-}$の值 が高く、Ca ${ }^{2+}$ の值が他の井戸に比べ低い $(2.4 \mathrm{mg} / \mathrm{L})$ ことである。また、この井戸に近接する稲作用に 利用されている井戸からも $0.15 \mathrm{mg} / \mathrm{L}$ という比較 的高濃度のホウ素が検出された。この井戸の水質 も同様の特徵を示した。他の 2 本の井戸について
は、養老渓谷温泉郷から $10 \mathrm{~km}$ ほど北に位置する 徳氏・柿木台地区にある。徳氏地区の井戸では0.38 $\mathrm{mg} / \mathrm{L}$ 、杮木台地区の井戸では $0.49 \mathrm{mg} / \mathrm{L}$ のホウ素 が検出された。徳氏地区の井戸は、飲み水として も利用されていたようである。これら 2 本の井戸 の水質も、朝生原地区の井戸水と同じ特徵を持っ ていた。

\section{3 化石水との比較}

自然界における存在量の項でも述べたが、ホウ 素は海水中にも $4.5 \mathrm{ppm}$ 程度含まれている元素で ある。瑞沢川流域付近で採取されている化石水に も同程度のホウ素が含まれている。表 1 に、海水 と現地で採水した化石水(かん水)の 2 サンプル、 旧指針值 $(0.2 \mathrm{mg} / \mathrm{L})$ を超過した21本の地下水サン 
表 1 旧指針值を超過した21サンプルのホウ素 /ナトリウムモル比およびホウ素/塩素 モル比

Table $1 \mathrm{~B} / \mathrm{Na}$ and $\mathrm{B} / \mathrm{Cl}$ ratios of contaminated 21 samples

\begin{tabular}{|c||cc|}
\hline & $\mathrm{B} / \mathrm{Na}$ & $\mathrm{B} / \mathrm{Cl}$ \\
\hline \hline $\mathrm{M} 0-46$ & 0.00875 & 0.04302 \\
\hline $\mathrm{Y}-9$ & 0.00240 & 0.09154 \\
\hline $\mathrm{M} 0-33$ & 0.00504 & 0.13792 \\
\hline $\mathrm{M} 0-29$ & 0.00508 & 0.19189 \\
\hline $\mathrm{MK}-5$ & 0.00473 & 0.01508 \\
\hline $\mathrm{MM}-15$ & 0.00453 & 0.12155 \\
\hline $\mathrm{MM}-24$ & 0.00252 & 0.11145 \\
\hline $\mathrm{M} 0-18$ & 0.00450 & 0.08916 \\
\hline $\mathrm{M} 0-28$ & 0.00610 & 0.18097 \\
\hline $\mathrm{M} 0-14$ & 0.00638 & 0.14898 \\
\hline $\mathrm{Y}-34$ & 0.00487 & 0.19719 \\
\hline $\mathrm{Y}-27$ & 0.00325 & 0.14214 \\
\hline $\mathrm{Y}-36$ & 0.01288 & 0.23909 \\
\hline $\mathrm{MK}-2$ & 0.01136 & 0.26059 \\
\hline $\mathrm{MK}-7$ & 0.00389 & 0.10256 \\
\hline $\mathrm{MK}-6$ & 0.00377 & 0.13043 \\
\hline $\mathrm{Y}-1$ & 0.00165 & 0.00254 \\
\hline 温泉-3 & 0.00169 & 0.00238 \\
\hline 温泉-2 & 0.00341 & 0.01065 \\
\hline 温泉-4 & 0.00139 & 0.00181 \\
\hline 温泉-1 & 0.00188 & 0.00305 \\
\hline 化石水(妙楽寺) & 0.00153 & 0.00232 \\
\hline 海水 & 0.00105 & 0.00083 \\
\hline 化石水(大上) & 0.00091 & 0.00073 \\
\hline
\end{tabular}

プルのホウ素／塩素モル比を示した。化石水のホ 门素／塩素モル比 $(\mathrm{B} / \mathrm{Cl})$ は、それぞれ0.00073 0.00232程度であり、海水の0.00083とあまり変わ らない。養老川流域で温泉用に利用されている 6 本の地下水では、0.00181 0.01065程度の值に なっており、海水に比較的近い值を示す。しかし、 一般家庭の井戸から採取した污染地下水のホウ素 /塩素モル比は、0.01508～0.26059の間であり化 石水のホウ素／塩素モル比とは明らかに異なる。 ホウ素/ナトリウムモル比についても同じような 傾向を示す。

図 4 は、ホウ素濃度が旧指針值を超過していた サンプル、旧指針值の半分以上の值を示したサン プル、定量限界以下だったサンプル、化石水、海 水などをトリリニアダイアグラムにプロットした ものである。ホウ素濃度の高いサンプルは、アル カリ非炭酸塩型と、アルカリ重炭酸塩型に大きく
分けられた。前者には海水や、化石水と考えられ る地下水が該当し、後者には、その他のホウ素濃 度の高いサンプルが該当する。

\section{5. 污染源の推定}

\section{1 污染源の推定}

ホウ素による地下水污染について、第 1 章で述 べたような污染源が従来考えられていたが、本研 究対象地域における污染源は従来明らかになって いる污染源とは別のものであると考えられる。対 象地域付近は火山地带ではなく、海岸からも数 $\mathrm{km}$ 離れている。また、人為的な污染源となりえ るような工場や飛灰(フライアッシュ)などの処分 施設もない。

污染源を推定するために、旧指針值を超過した 21 サンプルの水質データにクラスター分析を適用 した。クラスター分析の手法については、水質デー タにクラスター分析の各手法を適用し、得られた デー夕を検討した結果ウォード法を採用した。図 5 のデンドログラムに示したように、この地域の 地下水は大きく 3 つに分類できた。表 2 にそれぞ れの分類の平均水質を示した。これをへキサダイ アグラムで表現すると図6のようになる。以上の 解析から 3 つの分類はそれぞれ次のような特徴を もつ地下水であることが判明した。type $\mathrm{A}$ は $\mathrm{Cl}$ ： $\mathrm{Na}$ が海水に近いことから化石水型（アルカリ非炭 酸塩型)の地下水といえる。EC は海水の 10 分の 1 程度である。ホウ素の平均濃度は $0.88 \mathrm{mg} / \mathrm{L}$ と高 い值を示している。このタイプに分類された 4 本 のサンプルはいずれも温泉用もしくはガス採取用 として採水されているものである。海水や化石水 に代表されるようなアルカリ非炭酸塩型の地下水 といえる。type Bの地下水は、type Aの地下水と 近似しているが、ECの值が type A の半分ほどで あり、また、 $\mathrm{Na}^{+}$の值 $(543 \mathrm{mg} / \mathrm{L})$ に比べ $\mathrm{Cl}^{-}$の值 $(267 \mathrm{mg} / \mathrm{L})$ が低くなっている。このタイプの地下 水も温泉として利用されているものである。type $\mathrm{C}$ は $\mathrm{Na}^{+} 、 \mathrm{HCO}_{3}^{-} 、 \mathrm{EC}$ などが高い值をとる。アル カリ重炭酸塩型の地下水といえる。これは陽イオ ン交換の進んだ被圧地下水に特徴的な水質であ る。Type Bは、デンドログラムのステージを一 段あげると、Type Cに分類されるものであるが、 


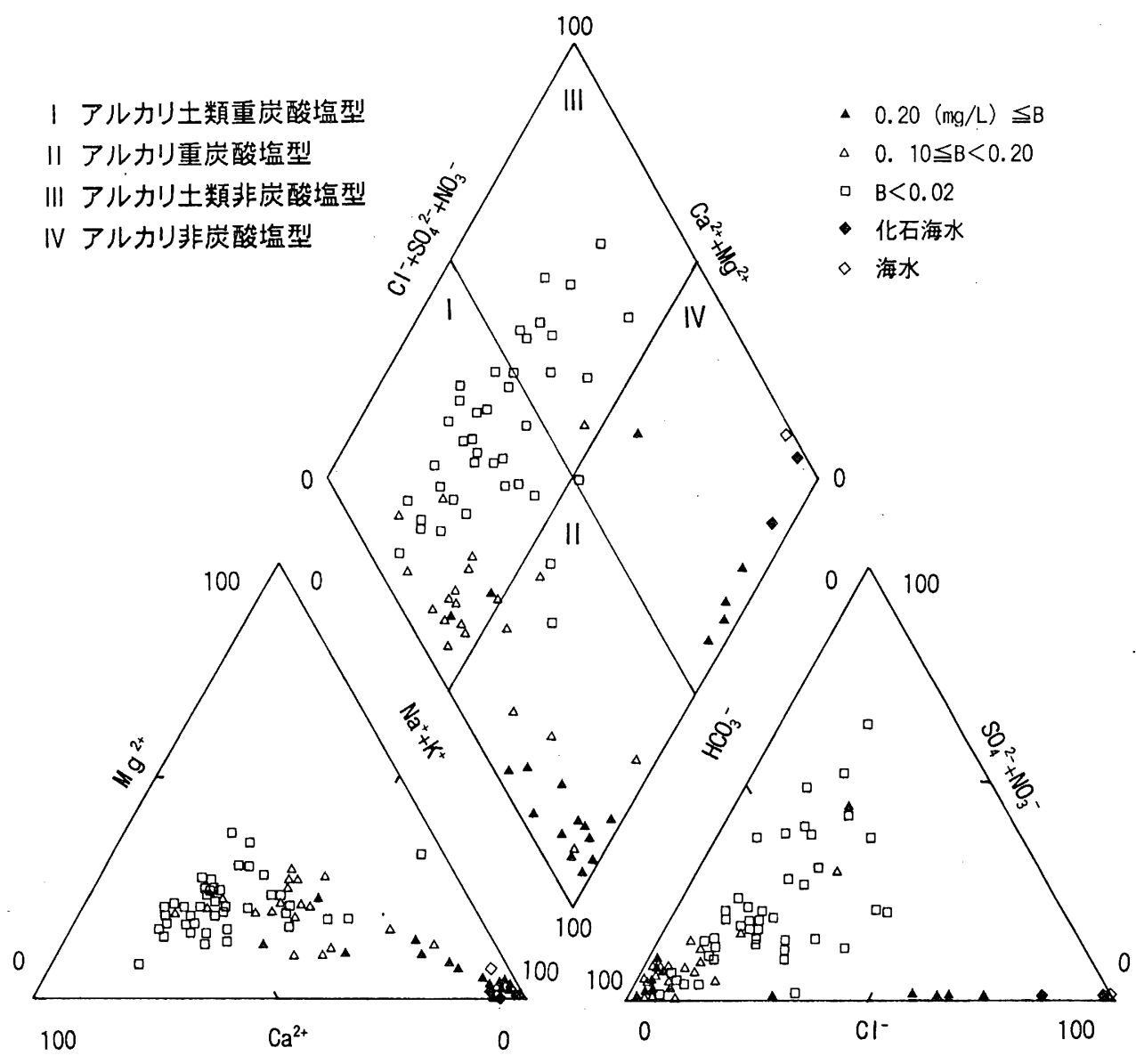

図 4 ホウ素濃度別に分類したトリリニアダイアグラム

Fig. 4 Trilinear diagram by the concentrations of boron.

表 2

タイプ別の平均水質

Table 2 Mean chemical composition by the water quality types.

\begin{tabular}{|r||r|r|r|r|r|r|r|r|r|r|r|r|r|r|}
\hline & 構成数 & $\mathrm{p} \mathrm{H}$ & $\mathrm{E} \mathrm{C}$ & $\mathrm{C} \mathrm{I}$ & $\mathrm{N} \mathrm{O}_{3}$ & $\mathrm{~S} \mathrm{O}_{4}$ & $\mathrm{H} \mathrm{C} \mathrm{O}_{3}$ & $\mathrm{~B}$ & $\mathrm{~S} \mathrm{i}$ & $\mathrm{C} \mathrm{a}$ & $\mathrm{M} \mathrm{g}$ & $\mathrm{N} \mathrm{a}$ & $\mathrm{K}$ & $\mathrm{T} \mathrm{O} \mathrm{C}$ \\
\hline \hline $\mathrm{A}$ & 4 & 7.72 & 4703 & 1230 & 0.0 & 0.0 & 1100 & 0.88 & 26.5 & 19.4 & 17.7 & 1150 & 43.8 & 30.4 \\
\hline $\mathrm{B}$ & 1 & 8.42 & 2460 & 267 & 0.0 & 0.0 & 1110 & 0.87 & 23.2 & 5.7 & 3.9 & 543 & 17.9 & 21.3 \\
\hline $\mathrm{C}$ & 16 & 8.22 & 691 & 12.7 & 10.7 & 14.0 & 365 & 0.38 & 21.7 & 17.4 & 5.8 & 165 & 25.1 & 5.1 \\
\hline
\end{tabular}

(単位はECが $\mu \mathrm{S} / \mathrm{cm} 、 \mathrm{C} 1$ より右はmg/L)

Type A と type Cの中間型と考えられる。

以上の考察から、ホウ素を高濃度に含む地下水 の類型には、主にアルカリ非炭酸塩型とアルカリ 重炭酸塩型の 2 種類に分類できる。アルカリ非炭 酸塩型の污染地下水については、そのホウ素/塩 素比などから主な污染源は化石水であると考えら れる。また、アルカリ重炭酸塩型の地下水に関し てはホウ素を多く含む海成堆積層からの地質起源 の污染が推定される。

\section{2 着色水との関係}

高濃度のホウ素を含む地下水には、もうひとつ の特徵がある。研究対象地域付近の一部の地下水 は着色していることが知られているが、ホウ素に より污染されていた地下水は着色しているものが 多かった。

千葉県における着色地下水の研究には、竹内 (1971)、石井(1973)などによるものがある。竹内 （1971）は、着色水を明らかに茶褐色を示す地下水 


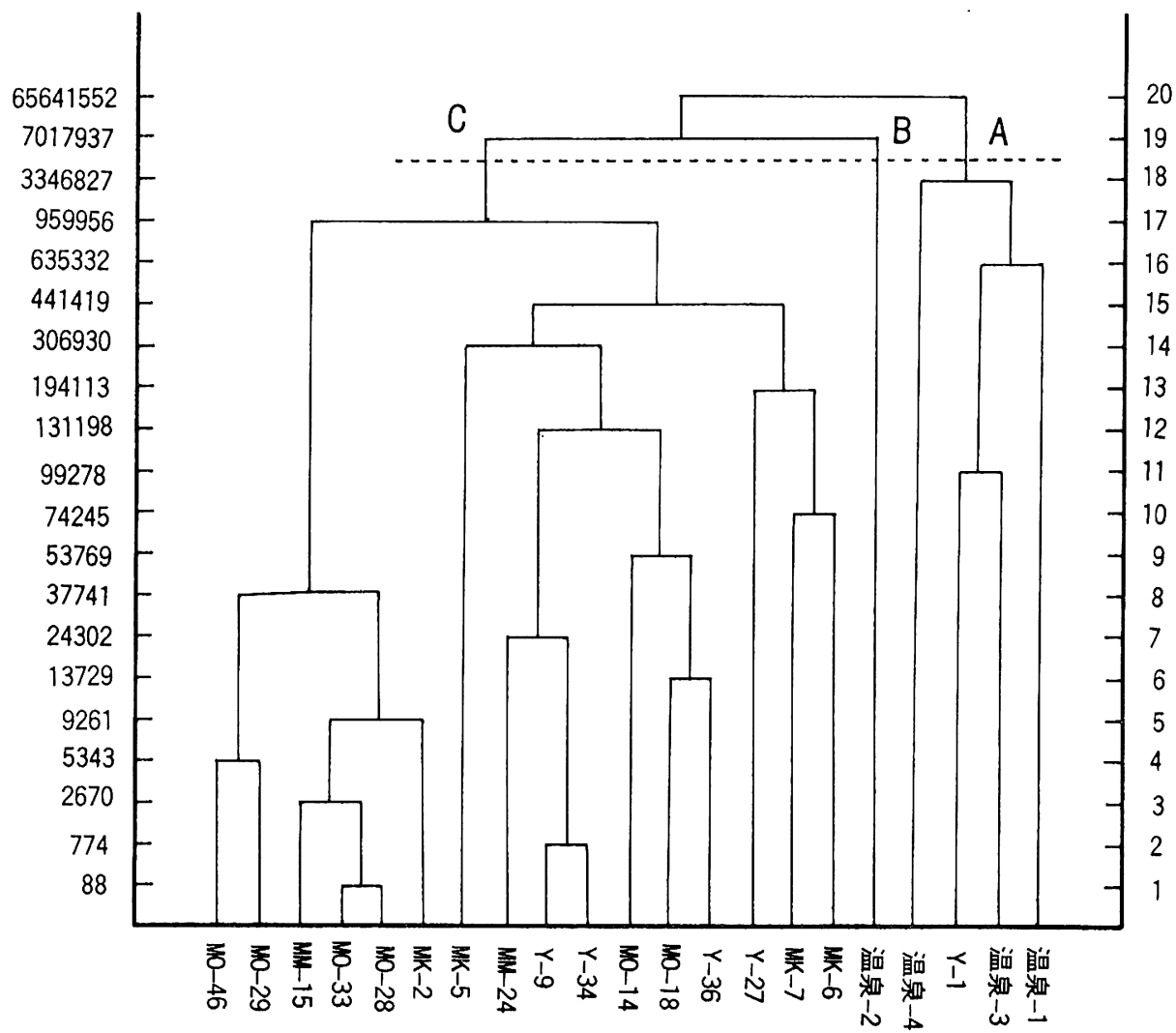

园 5 旧指針值を超過した21サンプルによるクラスター分析結果

Fig. 5 Dendrogram of the 21 contaminated samples.

と定義したうえで、着色水には水温が高いものが あること、ECの值が大きいこと、アルカリ重炭 酸塩型の水質を示し、陽イオン交換のすすんだ履 歴をもつ被圧地下水と考えられることなどを指摘 した。石井(1973)は、養老川に沿って市原市養老 地区から大多喜町葛藤地区にかけての着色水につ いて検討し、その分布範囲が養老川流域の市原市 柿木台から徳氏、古敷台、平野を経て高滝まで連 続しており、地表面からの勾配約1/10で着色水带 の分布がみとめられること、また葛藤、戸面、石 神、大久保と続く着色した地下水帯も、勾配がほ ぼ1/10でその連続性が推定されることなどを指摘 している。柿ノ木台層や梅ヶ瀬層をはじめこの付 近の地層は、砂岩・泥岩の互層といわれており、 透水性が小さいことが推定されている。着色水が 柿ノ木台層と、その下位の砂泥互層に多く分布し ているのは、地下水循環が、遅いかほとんど停滞
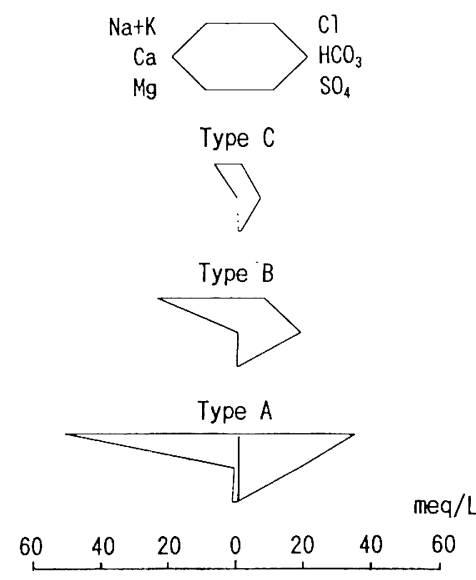

园 6 タイプ別のへキサダイアグラム

Fig. 6 Hexadiagrams by the water quality types.

している地層中で、堆積している有機物が溶出し て地下水を着色している(石井、1973)ためと考え 
られる。着色が著しい地下水は、地質の影響を強 く受けていると考えられる。ホウ素を高濃度に含 む地下水の特徴のひとつに茶褐色を呈しているこ とが多いということがあるが、特に養老川流域の 旧指針值以上にホウ素が検出された地下水は、す べて明らかに茶褐色を呈していた。茶褐色の原因 物質は、フミン酸と考えられている。フミン酸は、 樹木組織の主構成分であるリグニンやセルロース が、樹木枯死倒壊後、水中でバクテリア・菌類に よる分解をうけ、生化学的変化を受けて生成する 物質である(佐々木・長谷川、1979)。そして、着 色水が陽イオン交換のすすんだ履歴をもつ滞留性 の被圧地下水であることは前述したように竹内 (1971)の研究で明らかとなっている。着色してい る地下水の多くは地質の影響を強く受けているア ルカリ重炭酸塩型である。着色水がみられる地域 において、ホウ素濃度が高い地下水が、茶褐色を 呈しているということは十分に考えられることで ある。

\section{6. まとめ}

ホウ素が指針值を越えて検出されたサンプルで は $\mathrm{Na}^{+} 、 \mathrm{Cl}^{-} 、 \mathrm{HCO}_{3}^{-}$EC 濃度などが高くなる傾 向があった。トリリニアダイヤグラムでは、ホウ 素濃度の高い地下水はアルカリ重炭酸塩型の水質 を示し、濃度が低い地下水ほどアルカリ土類重炭 酸塩型の水質に遷移していくことが判明した。

そして、クラスター分析の結果、ホウ素が多く 含ま机る地下水には、アルカリ非炭酸塩型とアル カリ重炭酸塩型の 2 種類があることが明らかと なった。アルカリ非炭酸塩型の污染地下水につい ては、ホウ素の主な供給源は化石水であると考え られる。また、アルカリ重炭酸塩型の地下水に関 しては地質起源の污染が推定される。地質の影響 を受けやすい被圧地下水でホウ素濃度がもっとも 高くなっており、地質の影響がより少ないアルカ リ土類重炭酸塩型を示す浅層地下水ほどホウ素濃 度が低くなっているからである。粘土鉱物を多く 含む海成堆積岩には、一般に火成岩に比べて多量 のホウ素が含まれており、本地域の地層中にもホ ウ素が高濃度で存在していることが尔想される。 また、高等植物においては細胞の成熟と分化の過
程がホウ素に依存することが明らかとなってお り、フミン酸を多く含む滞留性の地下水に、腐植 質起源のホウ素が含まれている可能性も十分に考 えられる。以上の考察から、本地域での温泉水、 かん水(アルカリ非炭酸塩型地下水)中のホウ素に ついては主に化石水起源、温泉やかん水以外のそ の他の污染地下水(アルカリ重炭酸塩型地下水) 中 におけるホウ素は地質起源であると推定する。ま た、温泉水、かん水のサンプルにも着色がみられ るものがあり、それらの地下水には地質起源のホ ウ素も污染源の一つになっていることが推定され る。

また、本研究対象地域で得られたデータをみる かぎりでは、温泉やガス採取用などの、特殊な井 戸を除いた地下水中からは、新環境基準の $1.0 \mathrm{mg} / \mathrm{L}$ を超過したサンプルはなかった。ちなみに、環境 庁 (1999) の報道発表資料によると、平成 6〜8 年 度に調査した503サンプルの地下水では、 $0.1 \mathrm{mg} / \mathrm{L}$ を越えたものは58点あったが、 $1.0 \mathrm{mg} / \mathrm{L}$ を超過し たものは 2 点のみであった。

\section{謝 辞}

本研究は平成10年度クリ夕水・環境科学振興財 団研究助成「ホウ素による地下水污染の実態の解 明」(代表：田瀬則雄)による成果の一部である。 千葉県睦沢町の今関雄一氏および合同資源産業株 式会社の江澤晴雄、桶口康則の両氏には、調查の 際御協力頂きました。また、筑波大学応用生物化 学系の東照雄教授および査読者の方から数多くの 貴重な御意見を賜りました。記して感謝の意を表 します。

\section{参考文献}

五十嵐敏文・下垣久(1998)：バッチ法およびカラム法 によるホウ素の地中移行特性. 地下水学会誌、40-2、 121-132.

石井皓 (1973)：着色自噴水について，榧根勇編「地下 水資源の開発と保全」、水利科学研究所、234-239. 石川剛志・中村栄三 (1989)：ホウ素の同位体地球・宇

宙化学. 地球化学、23、23-34.

磯崎昭徳 (1975)：天然水中の微量ホウ酸とテトラフル 
オロホウ酸イオンの分別定量. 516-520.

内海喻・磯崎昭徳 (1967)：天然水中のホウ素の抽出吸 光光度定量. 日本化学会誌、88-5、545-549.

大森昌衛・端山好和・掘口万吉(1986)：「日本の地質

3 関東地方」共立出版、246-247.

環境庁 (1999)：平成10年度地下水質測定結果につい て.

金子文宜 (1995)：下葉県に㧈ける地下水の特性とその 農業利用に関する研究. 一葉県農業試験場特別報告、 29、1-62.

建設省建設技術協議会技術管理部会水質連絡会 (1997)：

「河川水質試験方法(案) 1997年版試験方法編」. 技法 堂出版、801-809.

检井弘・田中英彦 (1993)：「生体微量元素」廣川書店、 154-156.

佐々木清一・長谷川寿喜訳 (1979)：「土塞学」博友社、 58-78.

佐藤一男 - 坂田昌弘(1988)：各種元素の土塞中移行機 構 (その 1 ) 一土塨中移行過程のモデル化一. 電力中 央研究所報告、T86096、1-29.

竹内皓 (1971)：下-葉県小系川流域の深層地下水の水質 について. ハイドロロジー、4、5-9.
西村雅吉 (1955)：温泉のホウ素含有について．日本化 学会誌、76-6、584-588.

日本化学会編 (1992)：「季刊化学総説 NO.14、陸水の 化学」学会出版センター、92p.

日本環境管理学会 (1994)：「新水道水基準ガイドブッ ク」丸善株式会社、167-168.

眞柄泰基・相沢貴子・幸喜稔・月川由紀子・日野隆 信 ·渡部高弘 - 黒河雄幸 - 徳永則正 - 西村哲治 （1993）：「平成 6 年度水質管理調査報告書」厚生省、 $90 \mathrm{p}$.

武藤覚(1954)：硼素の地球化学的研究(第 9 報) 本邦に おける嗍素を多く含む鉱泉の特色 (1).日本化学会誌、 75-4、59-62.

Davldson, G.R. and Basset, R.L.(1993): Application of Boron Isotopes for Identifying Contaminants such as Fly Ash Leachate in Groundwater. Environ. Sci. Technol, 27, 172-176.

Leenhouts, J. M, Basset, R.L. and Maddock, T. (1998): Utilization of Intrinsic Boron Isotopes as Co-Migrating Tracers for Identifying Potential Nitrate Contamination Sources. Ground Water, 36-2, 240-250.

(受付：1999年 6 月28日、受理：2000年 4 月 8 日) 